\title{
EFFECT OF SUPPLEMENTED VERSUS NUTRITIONALLY INDUCED PROGESTERONE ON CONCEPTION RATE IN MODERATE YIELDING DAIRY COWS
}

\author{
Nasef, A. R.; (1) Mansour, A. N.; (2) Ramoun, A.A. ${ }^{(2)}$ and Serur, B.H. ${ }^{(2)}$ \\ (1) General authority of veterinary services \\ (2) Theriogenology Dept. Fac. Vet. Med. Kafrelshiekh University
}

\section{ABESTRACT}

The present study included two experiments, the first experiment aimed to test if direct supplementation of $P 4$ during post insemination period together with GnRH treatment on day 11post-isemination (PI) improve conception rate or not. The second experiment aimed to test whether peri-insemination feeding on fatty acids supplemented feed could improve conception rate or not. Cows in experiment $1(n=96)$ were fed on the basal diet $(B)$ and randomly allotted into 3 groups $v z$ : $G 1 B(n=34)$ whereas cows received intravaginal insertion of CIDR (controlled internal drug release device) on Day 1 PI whereas Day 0 was the day of insemination plus single I/M injection of GnRHa (0.02 $m g$ buserelin, Receptal) on Day 11 PI. The second group G2B $(n=30)$ received the same treatment regime of G1B plus 2 injections of $250 \mathrm{mg}$ of progesterone (Cidolut-Depot) on Days 1 and 3 PI. The $3^{\text {rd }}$ group $(G 3 B$, control $n=32)$ received no treatments. The results of the present study showed a decrease in the conception rate in both G1B and G2B although there was a significant increase in the serum P4 concentration on Day 3 and 8 PI compared with the control. In contrast there was a significent increase $(P<0.01)$ in the $C R$ in cows fed fatty acids supplemented feed compared with the control (75 vs $62.5 \%$ ). It could be concluded that one of the beneficial effects of peribreeding feeding cows on fatty acids supplemented feed is enhancing endogenous progesterone secretion which is being better than direct exogenous progesterone supplementation in improving conception rate in moderate yielding dairy cows. 


\section{INTRODUCTION}

Reproductive performance of dairy cows reared under modern intensive breeding systems has declined as indicated by a decrease in the CR (Washburn et al., 2002 and Maillo et al., 2013) and increase in the services per conception (Jorritsma et al., 2000 and Aungier et al., 2014). The causes of low conception rate are multifactorial amongst which is low progesterone concentration during early post- breeding period (Crowe et al., 2014). Serum progesterone concentration during early pregnancy is critical for embryo / conceptus survival (McNeill et al., 2006 and villarroel et al., 2004); development (Shams-Esfanabadi, and Shirazi 2006; Wiltbank et al., 2006 and Green et al., 2010) and growth (Thatcher et al., 2001; Carter et al., 2008; Beltmana et al., 2009 and Maillo et al., 2013). Cows failed to conceive had low progesterone concentration during early post- breeding interval between days: 10 and 16 (Henrick et al., 1971); 1-6 (Parr et al., 1993); 3 and 8 (Mann and Lamming, 1999) and 4-7 (Mann and Lamming, 2006). Early postbreeding progesterone supplementation resulted in increased pregnancy rate (Mann and Lamming, 2006) from 35\% to $48 \%$ (Sandra et al., 2007). Early post-breeding serum progesterone concentration could be increased either by exogenous administration of progesterone (Cleeff et al., 1991 and Mann and Lamming et al., 1999) or inducing ovulation of a dominant follicle using GnRH or hCG with subsequent formation of an accessory CL (Lo'pez-Gatius et al., 2004 and Bartolome et al., 2005) or both together (Villarroel et al., 2004). Progesterone was directly 
administrated via short-term insertion of CIDR (Carter et al., 2008; Sandra et al.,2007; Basa, 2014 and Maillo et al., 2013) or injection of progesterone on Days 1 to 4 (Starbuck et al., 1999) or both together (Macmillan et al., 1986; Stevenson and Mee, 1991). Feeding on diets supplemented with fatty acids especially polysaturated types (PUFA) plays a vital role in improving cows fertility (Sklan et al., 1994 and Childs et al., 2008) through increasing conception rate (Son et al., 1996; Garcia- Bojalil et al., 1998; Mattos et al., 2004 and Staples et al., 1998). The PUFA produced their beneficial effect on the conception rate by increasing serum P4 concentration through two ways, the first is elevating the serum level of its precursor, cholesterol, (Grummer and Carroll, 1991; Bonnette et al., 2001 and Silvestre et al., 2011) and the second is omega-3 fatty acids, linolenic acid which compete with the arachidonic acid for binding sites of a key enzyme, cyclo-oxygenase, which is necessary for the synthesis of PGF2 $\alpha$ thus reducing PGF2 $\alpha$ secretion (Mattos et al., 2003 and Mattos et al., 2004) leading to maintenance of CL. In cattle, $40 \%$ of conception loss occurs in the period from day 8 to 16 of pregnancy (Thatcher et al., 1993). Because a substantial proportion of this loss may be attributed to inadequate circulating P4 concentration (Carter et al., 2008 and Beltmana et al., 2009), the present work was designed to study the effect of administration of progesterone during post-insemination period together with GnRH on Day 11 post-insemination in comparison with periinsemination feeding fatty acids-supplemented diet on subsequent conception rate. 


\section{MATERIALS AND METHODS}

\section{II.1. Animals and management:}

The selected cyclic cows were $3.2 \pm 1.2$ years old, had a body weight of (means \pm SD) $520 \pm 27 \mathrm{Kg}$ and a body condition score of $3.1 \pm$ 0.4 (on 5 point scale $1=$ thin and 5 obese, (Wildman et al., 1982). Animals were in $2^{\text {nd }}$ to $4^{\text {th }}$ lactation and producing $22 \mathrm{Kg}$ /daily per cow of 3.5 fat corrected milk. Cows were milked twice daily and production was measured for individual cows once monthly. The cows were fed on basal diet (B) and fatty acids (F) supplemented diets (Table 1 and 2) to meet the requirements of maintenance and milk production according to $N R C$ (2001).

Table (1): Formulation of basal and experimental diets on DM basis\%

\begin{tabular}{|c|c|c|}
\hline Feed ingredients & Basal diet & Experimental diet \\
\hline Corn & $30.21 \%$ & $28.7 \%$ \\
\hline Soy & $17.0 \%$ & $7.0 \%$ \\
\hline Mix pro & & $14.12 \%$ \\
\hline Corn silage & $23.98 \%$ & $22.77 \%$ \\
\hline Hay & $28.77 \%$ & $27.44 \%$ \\
\hline Vitamins and Minerals & $0.04 \%$ & $0.07 \%$ \\
\hline $\mathrm{CP}$ & $15.8 \%$ & $15.6 \%$ \\
\hline TDN & $68 \%$ & $71 \%$ \\
\hline NFC & $41.4 \%$ & $39.3 \%$ \\
\hline NDF & $34.2 \%$ & $34.5 \%$ \\
\hline NEL & $1.59 \mathrm{Mcal} / \mathrm{kg}$ & $1.68 \mathrm{Mcal} / \mathrm{kg}$ \\
\hline
\end{tabular}

Table (2): Composition of linseed Mix-Pro.

\begin{tabular}{||l||l||}
\hline \multicolumn{1}{|c||}{ Fatty Acids } & Mix Pro Relative \% of the total identified fatty acid \\
\hline \hline Myristic Acid(14:0) & 0.21 \\
\hline Palmitic Acid (16:0) & 12.41 \\
\hline Palmitoleic Acid(16:1.9) & 0.25 \\
\hline Stearic (18:0) & 5.64 \\
\hline Oleic Acid (18:1.9c) & 23.67 \\
\hline Linoleic Acid (18:2. 9,12 all cis) & 26.76 \\
\hline Conjugated Linoleic Acid "CLA" (18:2, 9-cis, 11-trans,) & 2.70 \\
\hline \&-Eleostearic Acid (18:3,9 cis,11trans, 13 trans) & 0.22 \\
\hline Gondoic acid (20:1, 11cis) & 0.17 \\
\hline
\end{tabular}

Mix-Pro. Was manufactured by Kemit (www.Kemit.net), Sadat City- Industrial Zone No. $6^{\text {th }}$. Tel.: $+20482630193 / 4$, the MixPro product is formulated from $40 \%$ Linseed Meal, $30 \%$ Soybean meal and $30 \%$ Cotton seed meal.

Kafrelsheikh Vet. Med. J. Vol. 14 No. 1 (2016) 
They were kept indoors throughout the year in yards where $50 \%$ of the yard was sheltered and the animals had free access water. The animals had normal calving and puerperium as has been declared from herd records. They were free from infectious diseases during the course of the experiment and also vaccinated against FMD and lumby skin diseases.

\section{II.2. Experimental design:}

\section{II.2.1. Experiment 1:}

Cyclic 112 cows were assigned on the basis of feeding basal diet (GB, n=96) or fatty acids-supplemented diet (GF, $n=16)$. The cows in the main group, GB, were allotted into 3 subgroups viz: G1B (n=34), G2B $(n=30)$ and G3B $(n=32)$. Cows in G1B were administrated progesterone via intravaginal insertion of controlled internal drug release device (EAZI- BEED, CIDR, Pfizer Animal Health) for 9 days beginning from Day 1 post-insemination (Villarroel et al., 2004) where Day 0 was the day of insemination. The cows also received single I/M injection of GnRHa (0.02mg Buserelin, 5ml Receptal, Intervet international GmbHGermany) on Day 11/ post-insemination (Willard et al., 2003). Cows in G2B received the same treatment regime given to G1B plus two I/M injections of $250 \mathrm{mg}$ progesterone (Cidolut-Depot, each amp. contains $250 \mathrm{mg}$ progesterone carried on oily vehicle, Chemical Industries Development "CID"-Giza-A.R.E) on Days 1 and 3 post-insemination. Cows in $\mathrm{G} 3 \mathrm{~B}$ (Control group, $\mathrm{n}=32$ ) received no treatments. 


\section{II.2.2. Experiment 2:}

Sixteen cyclic cows received fatty acids supplemented feed (Tables $1 \& 2$ ) for 26 days before and during 11 days left between two PGF2 $\alpha$ (Cloprostenol sodium, $500 \mathrm{mcg}$ present in two $\mathrm{ml}$ Estrumate, Schering-Plough Animal Health) I/M injections for synchronization of estrus. Thus the total pre-breeding period of feeding on fatty acids supplemented diet including 5 days (estrous induction period after PGF2 $\alpha$ injection) was 42 and continued thereafter. However 3 cows failed to show estrous signs following $2^{\text {nd }} \mathrm{PGF} 2 \alpha$ injection. Accordingly the number of animals in this group (GF) became 16.The cows in GF continued to receive the experimental diet after insemination till drying period. However cows in G3B (control group in the first exp.) fed on the basal diet were considered a control group for the second experiment.

\section{II.3. eproductive managements:}

\section{II.3.1. Estrous detection and Breeding:}

Cows in exp. 1 (G1B, G2B and G3B) and in exp. 2 (GF) were observed during 5days following $2^{\text {nd }}$ PGF2 $\alpha$ injection for estrous signs in the induced estrous. Cows expressing mounting activities with vaginal mucous discharge coming from the vulva and seen in standing heat were inseminated 12 hrs. after onset of estrous phase (Pursley et al., 1997).

\section{II.3.2. Pregnancy diagnosis:}

Cows were rectally palpated on Day 42 post-insemination for pregnancy diagnosis. Conception rate was calculated by dividing the number of conceived cows on the total number of inseminated cows. 


\section{Blood sampling:}

Blood samples were collected from jugular vein on Days 1, 3, 8 and 17 post-insemination from cows in both experiments where day 0 was the day of insemination. Blood samples were transferred on ice to the laboratory where they were centrifuged at $2000 \mathrm{xg}$ for 20 minutes at $4^{0} \mathrm{C}$. The harvested serum was stored at $-20^{\circ} \mathrm{C}$ until analysis.

\section{Assays:}

\section{IV.1. Progesterone assay:}

Serum progesterone concentrations were determined by radioimmunoassay according to the $\mathrm{P} 4$ kits producers instructions. The sensitivity of P4 assay was $0.2 \mathrm{ng} / \mathrm{ml}$. The intra and inter assay coefficient of variation for 3 assays were $8.1 \%$ and $7.9 \%$ respectively (Lo'pez-Gatius, et al., 2007).

\section{IV.2. Serum cholesterol:}

The total cholesterol concentration was determined using enzymatic colorometric and point method as has been described by Siedel et al., (1985).

\section{Statistical Analysis:}

The statistical analysis was made according to $S A S$ (2004). The serum concentration of progesterone and cholesterol were presented as mean \pm SDM. Chi-square test was used to compare conception rate between each of experimental groups and control group as well as among all groups. The t-test was used to compared serum concentrations of progesterone, cholesterol between each of experimental groups and control group. At the same time analysis of variance (ANOVA) was used to compare among all groups including control in relation to serum concentrations of $\mathrm{P} 4$, cholesterol. 


\section{RESULTS}

\section{III.I. Comparison of conception rate among different treatment groups:}

There was a significant $(\mathrm{p}<0.01)$ variation among conception rates in different treatments groups with highest incidence in GF group $(12 / 16 /, 75 \%)$ and lowest in G1B $(2 / 34,5.9 \%)$. Also the conception rate showed significant $(\mathrm{p}<0.01)$ increase in GF compared with control (G3B, 20/32, 62.5\%) and each of G1B (2/34, 5.9\%) and G2B (2/30, $6.7 \%$ ). Moreover, the conception rate in the G3B showed a significant ( $\mathrm{p}$ $<0.01$ ) increase compared with either of G1B and G2B.

Table (3): Conception rate in different treatment groups.

\begin{tabular}{|c|c|c|c|c|c|}
\hline \multirow{2}{*}{ Groups } & \multirow{2}{*}{$\begin{array}{c}\text { Total } \\
\text { number }\end{array}$} & \multicolumn{2}{|c|}{ Conceived } & \multicolumn{2}{|c|}{ "Non-conceived } \\
\hline & & Number & $\%$ & Number & $\%$ \\
\hline G1B & 34 & 2 & 25.9 & 32 & 94.10 \\
\hline G2B & 30 & 2 & 6.70 & 28 & 93.30 \\
\hline GF & 16 & 12 & 75 & 4 & 25 \\
\hline G3B & 32 & 20 & 62.5 & 12 & 37.50 \\
\hline
\end{tabular}

$\mathrm{Chi}^{2}=9.37 * * * *=$ Significant at $(\mathrm{P}<0.01)$

The groups G1B and G2B are related to first experiment.

The group GF is related to 2nd experiment.

G3B is a control group for the groups in both 1st and 2nd experiments.

\section{II.2. omparison of serum progesterone profiles on post-insemination} days $1,3,8$ and 17 in different groups:

The serum progesterone concentration on Day 1 PI showed significant $(\mathrm{p}<0.01)$ increase in GF compared with other treatments groups. On Day 3 PI, there was significant $(\mathrm{p}<0.01)$ decrease in The serum progesterone concentration in G3B compared with each of G1B or G2B or GF. The serum progesterone concentration showed significant ( $p$ $<0.01$ ) increase in G2B Vs G1B; G1B Vs G3B and G3B Vs GF on Day 8 PI. On Day 17 PI, while the highest serum progesterone concentration was 
recorded in GF, the lowest was recorded in G1B. On other hand, although serum progesterone concentration in $\mathrm{G} 2 \mathrm{~B}$ and $\mathrm{G} 3 \mathrm{~B}$ showed non significant variation, it was significantly $(\mathrm{p}<0.01)$ higher than G1B and lower than GF (Table, 4)

Table (4): Mean \pm SD of Serum progesterone profile at different post insemination (PI) days in different groups.

\begin{tabular}{|c||c||c||c||c||}
\hline Days post-insemination (PI) & G1B & G2B & GF & G3B \\
\hline \hline Day-1 & $0.76 \pm 0.43^{\mathrm{c}}$ & $0.88 \pm 0.36^{\mathrm{c}}$ & $1.35 \pm 0.07^{\mathrm{a}}$ & $1.11 \pm 0.49^{\mathrm{b}}$ \\
\hline Day-3 & $1.70 \pm 0.77^{\mathrm{a}}$ & $1.75 \pm 0.37^{\mathrm{a}}$ & $1.64 \pm 0.12^{\mathrm{a}}$ & $1.43 \pm 0.47^{\mathrm{b}}$ \\
\hline Day-8 & $2.69 \pm 0.46^{\mathrm{b}}$ & $2.87 \pm 0.55^{\mathrm{a}}$ & $1.98 \pm 0.26^{\mathrm{d}}$ & $2.13 \pm 0.48^{\mathrm{c}}$ \\
\hline Day-17 & $2.03 \pm 1.08^{\mathrm{c}}$ & $2.30 \pm 1.10^{\mathrm{b}}$ & $3.90 \pm 1.63^{\mathrm{a}}$ & $2.90 \pm 1.23^{\mathrm{b}}$ \\
\hline
\end{tabular}

Means within the same row of different letters are significantly different at $(\mathrm{p}<0.01)$

The groups G1B and G2B are related to first experiment.

The group GF is related to 2nd experiment.

G3B is a control group for the groups in both 1st and 2nd experiments.

\section{Comparison of blood cholesterol among different treatment groups on PI Days 1 and 3.}

The serum cholesterol levels on Day 1 showed significant $(\mathrm{p}<$ 0.01) variation among treated groups with highest level in GF $(373.67 \pm 35.92 \mathrm{mg} / \mathrm{dl})$ and lowest level in G3B $(130.33 \pm 7.77 \mathrm{mg} / \mathrm{dl})$. The recorded levels in G2Band G1B were $(154.00 \pm 24.27)$ and $143.33 \pm$ $36.12 \mathrm{mg} / \mathrm{dl}$, respectively.

On PI Day 3, it was noted that although there was significant ( $\mathrm{p}<$ 0.01) increase in GF group compared with all groups, there was nonsignificant variation between $\mathrm{G} 1 \mathrm{~B}$ and $\mathrm{G} 2 \mathrm{~B}$. However the serum cholesterol level on Day 3 showed significant $(\mathrm{p}<0.01)$ increase in either of G1 or G2B compared with G3B. 
Nasef, A. R. et., al.

Table (5): Serum cholesterol concentration in different treatment groups at different periods.

\begin{tabular}{|c|c|c|c|c|}
\hline \multirow{2}{*}{ Post-insemination Day (PI) } & \multicolumn{4}{|c|}{ Treatment groups } \\
\hline & G1B & G2B & GF & G3B \\
\hline $1^{\text {st }}$ Day & $143.33 \pm 36.12^{\mathrm{d}}$ & $154.00 \pm 24.27^{\mathrm{c}}$ & $373.67 \pm 35.92^{\mathrm{a}}$ & $130.33 \pm 7.77^{\mathrm{e}}$ \\
\hline $3^{\text {rd }}$ Day & $143.33 \pm 31.07^{\mathrm{d}}$ & $147.33 \pm 24.44^{\mathrm{cd}}$ & $372.00 \pm 38.97^{\mathrm{a}}$ & $122.00 \pm 5.57^{\mathrm{f}}$ \\
\hline
\end{tabular}

Means within the same column of different litters are significantly different at $(\mathrm{p}<0.01)$.

The groups G1B and G2B are related to first experiment.

The group GF is related to 2 nd experiment.

G3B is a control group for the groups in both 1st and 2nd experiments

\section{DISCUSSION}

In contrast to what expected, the results of the present study showed a decrease in the conception rate in CIDR- GnRH treated group in spite CIDR application on Day 1 PI resulted in significant increase in the serum P4 concentration on Day 3 and 8 PI compared with the control. These results agree in part with that of Starbuck et al., (2001) who reported that too low and too high P4 concentrations on Days 5, 6, 7, PI were associated with reduced embryo survival. Mann and Lamming, (1999) attributed the decreased CR following CIDR insertion and removal to the fact that the early rise in $\mathrm{P} 4$ ( $2^{\text {nd }}$ day of estrous cycle) following CIDR insertion may activate precious secretion of PGF $2 \alpha$ resulting in shortening of the estrous cycle leading to failure of conception, and the time the delayed recovery of endogenous P4 by CL in response to increasing $\mathrm{LH}$ levels creates agape of low P4 that may threat pregnancy maintenance. In the same respect, Diaz et al., (1998) and Binelli et al., (2001) reported that the transient decrease in the P4 concentration following CIDR removal stimulate a hormonal situation 
similar to that occurring during the late of estrous cycle in cyclic cows whereas the decreased $\mathrm{P} 4$ levels results in increased development of oxytocin receptors with subsequent secretion of PGF2 $\alpha$ leading to luteolysis of CL and pregnancy loss. Regarding the effect of high P4 level during PI period on the embryonic development, Kerbler et al., (1997) reported that post-breeding P4 supplementation reduces blastocyst rate. They reported that the detrimental effect of P4 supplementation was reversed by $\mathrm{P} 4$-antagonist, $\mathrm{Ru}-486$, suggesting a role for P4 receptors in reducing such detrimental effect of increased P4 level. In the same respect, Carter et al., (2008) found that higher postbreeding P4 level increased $\alpha$-inhibin Production by cumulus-oocyte complex which may reduce embryonic development after cleavage. Furthermore, the reduced endometrial thickness induced by elevated serum P4 (Souza et al., 2011) represented another detrimental effect of P4 on the uterus reducing embryonic development. Based on the hypothesis of the current work, further supplementation of P4 by I/M injection on Days 1and 3 PI aiming to achieve a higher serum concentration of $\mathrm{P} 4$ in believe that it may achieve more better results in $\mathrm{CR}$ in $\mathrm{G} 2 \mathrm{~B}$, the results also proved the reverse of our expectation. Matching the conception rates with serum P4 concentrations on Days 1, 3, 8 and 17 PI in CIDR- GnRH treated (G1B); CIDR-GnRH plus P4 injections $(\mathrm{G} 2 \mathrm{~B})$ and control $(\mathrm{G} 3 \mathrm{~B})$ revealed that the $\mathrm{CR}$ is closely related to higher serum P4 on Days 1 and 17 rather on Days 3 and 8 PI. These results suggest that the beneficial effect of increasing PI serum P4 is related to early rise. However the rise in the postovulatory P4 concentration seems to improve $\mathrm{CR}$ through improving oocyte quality (Wiltbank et al., 2012) or enhancing growth through inducing changes in the endometrium rather than direct effect on the embryo itself (Bridges et 
al., 2013). Also Wiltbank et al., (2006) reported that $\mathrm{P} 4$ supplementation during postovulatory rise not in the early luteal phase increased embryo and IFN tau production. Furthermore, increasing PI serum P4 concentration by inserting CIDR after AI increased P4 concentration by $0.7 \mathrm{ng} / \mathrm{ml}$ and $\mathrm{CR}$ from $35 \%$ to $48 \%$ (Sandra et al., 2007) by overcoming the sensitivity of P4 receptors (Leory et al., 2008). Which ensure the beneficial effect of the P4 rise in the first PI day over the delayed rise on Days 3 and 8 is the higher $\mathrm{CR}$ in the control group compared with G1 and G2 in spite of the supplementation of P4 resulted in significant increase in $\mathrm{P} 4$ concentration in these 2 groups compared with control group on Days 3 and 8. Unlike direct P4 supplementation in the first experiment that might result in hormonal disturbances at the level of pituitary LH as sudden withdrawal of $\mathrm{P} 4$ source results in a gape of P4 during the recovery of LH or at the level of endometrial PGF2 $\alpha$ as sudden withdrawal of $\mathrm{P} 4$ results in development of oxytocin receptors with subsequent of PGF2 $\alpha$ secretion and pregnancy loss, feeding on fatty acids supplemented feed would keep P4 secretion with normal physiological levels and within proper time necessary for the success of conception. However the results of the current study this time came in accordance with the proposed hypothesis where there was a significant increase $(\mathrm{P}<0.01)$ in the $\mathrm{CR}$ in cows kept on fatty acids supplemented feed compared with the control (75 vs 62.5\%). Such increase in the CR may be attributed to the significant increase in the serum P4 concentration on Day $1 \mathrm{PI}$ as the situation in the control compared to G1B and G2B in the first experiment. However the significant increase in the serum P4 on Day 1 in cows fed fatty acid supplemented feed may be attributed to the significant increase in the serum cholesterol concentration ( $373.67 \pm 35.92$ vs $130.33 \pm 7.77$ in control) induced by 
feeding on the feed rich in PUFAs (linoleic and lenolenic acids). This explanation came in agreement with Childs et al., (2008) who reported that higher fertility in cattle fed diets enriched with PUFAs may be associated with increased circulating concentration of P4 in the luteal phase both before and after artificial insemination. They added that diets enriched with fatty acids significantly increased the concentration of cholesterol, the precursor, of synthesis of P4 by CL. Bonnette et al., (2001) in the same respect reported that addition of fats to dairy and beef diets have been shown to increase plasma cholesterol. Also Haag, (2001) concluded that polyunsaturated fatty acids (PUFAs) are precursors of cholesterol which is an accident to progesterone synthesized by CL. The benefits of feeding on fatty acids supplemented diet in increasing CR was not only restricted to increasing PI serum P4 concentration but also it had another beneficial effects. One of these beneficial effects was that pre-breeding feeding may be attributed to increasing size of the preovulatory follicle (Beam and Buttler, 1997 and Jenkins, 2004) and its steriodogenic ability (Coyne et al., 2008). Another beneficial effect was that feeding of fatty acids enriched diets reduces the endometrial secretion of PGF $2 \alpha$ and reducing sensitivity of CL to PGF $2 \alpha$ thus prolong functional life span of CL and allow it to increase P4 concentration and CR (Staples et al., 1998). Mattos et al., (2000) reported that feeding on PUFA increases herd pregnancy rates through blocking natural release of PGF2 $\alpha$ that occurs from day 17 to 19 of estrous cycle in case of small embryos unable to signal the uterus and prevent natural luteolysis. Linolenic acid (precursor of PGF2 $\alpha$ ) competes for binding sites of a key enzyme, cyclooxygenase-2 (PGHS-2) which is necessary for synthesis of PGF $2 \alpha$ by the endometrium resulting in increased CR (Mattos et al., 2003 and Mattos et al., 2004). 
It could be concluded that amongst beneficial effects of peribreeding feeding cows on fatty acids supplemented feed is enhancing endogenous progesterone secretion which is being better than direct exogenous progesterone supplementation in improving conception rate.

\section{REFERENCES}

- Aungier, S.P.; Roche, J.F.; Diskin, M.G. and Crowe, M.A. (2014): Risk factors that affect reproductive target achievement in fertile dairy cows. J. Dairy. Sci. 97:3472-3487.

- Basa, S.; Maquivara, M.G.; Coutinho, M.A.; da Silva, M.L.; Dayc, M.C.; Daglioa, S.; Harguindeguya, M. and Titlera, G.M.(2014): Effect of intrauterine administration of gonadotropin releasing hormone with glycerol on serum LH concentrations in lactating dairy cows, Anim. Reprod. Sci. 145:15 - 22.

- Bartolome, J.A.; Melendez,P.; Kelbert, D.; Swift, K.; McHale, J. and Hernandez, J. (2005): Strategic use of gonadotrophin-releasing hormone $(\mathrm{GnRH})$ to increase pregnancy rate and reduce pregnancy loss in lactating dairy cows subjected to synchronization of ovulation and timed insemination. Theriogenology, 63:1026-1037.

- Beam, S.W. and Butler, W.R. (1997): Energy balance and ovarian follicle development prior to the first ovulation in dairy cows receiving three levels of dietary fat. Biol. Reprod.56:133-142.

- Beltmana, M.E.; Lonerganab, P.; Diskinc, M.G.; Rochea, J.F. and Croweab, M.A. (2009): Effect of progesterone supplementation in the first week post conception on embryo survival in beef heifers. Theriogenology, 71: 1173-1179. 
- Binelli, M.; Thatcher, W.W.; Mattos, R. and Baruselli, P.S. (2001): Antiluteolytic strategies to improve fertility in cattle. Theriogenology, 56:1451-1463.

- Bonnette, T.R.; Whittier, J.C.; Engle, T.E. and Burns, P.D. (2001): Effect of fish meal supplementation on fertility in primiparous lactating beef cows. Proc. West. Sect., Am. Soc. Anim. Sci.79 (Suppl. 2): 14 (Abstr.).

- Bridges, G.; Day, M.; Geary, T. and Cruppe, L. (2013): Triennial Reproduction Symposium: deficiencies in the uterine environment and failure to support embryonic development. J. Anim. Sci. 91:30023013.

- Carter, F.; Forde, N.; Duffy, P.; Wade, M.; Fair, T. and Crowe, M.A.(2008): Effect of increasing progesterone concentration from Day 3 of pregnancy on subsequent embryo survival and development in beef heifers. Reprod. Fertil. Dev.; 20:368-375.

- Childs, S.; Carter, F.; Lynch, C.O.; Sreenan, J. M.; Lonergan, P.; Hennessy, A. A. and Kenny, D. A. (2008): Effect of n-3 PUFA supplementation on embryo recovery rate, quality and gene expression in beef heifers. Proceedings of the Irish Agricultural Research Forum. March, p 82.

- Coyne, G.S.; Morris, D. G.; Childs, S.; Kenny, D. A. and Waters, S. M. (2008): Effect of dietary n-3 polyunsaturated fatty acids on gene expression in the bovine uterus using microarray technology. Proceedings of the Irish Agricultuarl Research Forum. March, p. 14.

- Cleeff, J.v.; Drost M. and Thatcher, W.W. (1991): Effects of post insemination progesterone supplementation on fertility and subsequent estrous responses of dairy heifers. Theriogenology, 36:787-795. 
- Crowe, M.A.; Diskin, M.G. and Williams, E.J. (2014): Parturition to resumption of ovarian cyclicity: comparative aspects of beef and dairy cows. Anim. Reprod. Sci. 8:4053.

- Diaz, T.; Schmitt, E.J.; de la Sota, R.L.; Thatcher, M.J. and Thatcher, W.W. (1998): Human chorionic gonadotropin-induced alterations in ovarian follicular dynamics during the estrous cycle of heifers. J. Anim. Sci. 76:1929-1936.

- Garcia-Bojalil, C.M.; Staples, C.R.; Risco, C.A.; Savio, J.D. And Thatcher, W.W. (1998): Protein degradability and calcium salts of long-chain fatty acids in the diets of lactating dairy cows: reproductive responses. J. Dairy. Sci. 81:1385-1395.

- Green, J.C.; Okamura, C.S. and Lucy, M.C. (2010): Measurement of intrferone-tau (IFN-t) stimulated gene expression in blood leukocytes for pregnancy diagnosis within 18-20 d after insemination in dairy cattle. Anim. Reprod. Sci. 121, 24-33.

- Grummer, R.R. and Carroll, D.J. (1991): Effects of dietary fat on metabolic disorders and reproductive performance of dairy cattle. J. Anim. Sci. 69:3838-3852.

- Haag, M. (2001): Poly-unsaturated fatty acids: cellular role and clinical applications. Geneeskunde Med. J. 43. On-line: www.medpharm. co.za/safp/2001/nov/poly.html.

- Henricks, D.M.; Lamond, D.R.; Hill, J.R. and Dickey, J.F. (1971): Plasma progesterone concentrations before mating and in early pregnancy in beef heifers. J. Anim. Sci. 33: 450- 463. 
- Jenkins, T. (2004): Challenges of meeting cow demands for omega fatty acids. Florida Ruminant Nutrition Symposium. In: http://dairy. ifas.ufl.edu/files/rns/2004 /Jenkins.pdf.

- Jorritsma, R.; Jorritsma, H.; Schukken, Y.H. and Wentink, G.H. (2000): Relationships between fatty liver and fertility and some periparturient diseases in commercial Dutch dairy herds. Theriogenology, 54:1065-1074.

- Kerbler, T.L.; Buhr, M.M.; Jordan, L.T.; Leslie, K.E. and Walton, J.S. (1997): Relationship between maternal plasma progesterone concentration and interferon- $\tau$ synthesis by the conceptus in cattle. Theriogenology, 47:703-714.

- Leory, J.L.; Opsomer, M.R.; Van Soom, G.A.; Goovaerts, I.G.F. and Bols, P.E.J. (2008): Reduced fertility in high yielding dairy cows: are the oocyte and embryo in danger? Part 1: the impotence of negative energy balance and alterd corpus luteum function to the reduction of oocyte and embryo quality in high yielding dairy cows. Reprod. Domest.Anim. 43, 612- 622.

- López-Gatius, F.; Santolaria, P.; Yá niz, J.L. and Hunter, R.H.F. (2004): Progesterone supplementation during the early fetal period reduces pregnancy loss in high-yielding dairy cattle. Theriogenology, 62: 1529-1535.

- Lo'pez-Gatius, F.; Garbayo, J.M.; Santolaria P.; Yániz, J.; Ayad A. and Sousa, N.M. (2007): Milk production correlates negatively with plasma levels of pregnancy-associated glycoprotein (PAG) during the early fetal period in high producing dairy cows with live fetuses. Domest. Anim. Endocrinol. 32:29-42. 
- Macmillan, K.L.; Taufa, V.K. and Day, A.M. (1986): Effects of an agonist of GnRH (buserelin) in cattle. III. Pregnancy rates after a postinsemination injection during metoestrus or dioestrus. Anim. Reprod. Sci. 11: 1-10.

- Maillo, V.; Duffy, P.; O'Hara, L.; de Frutos, C. Kelly, A.K. and Lonergan $\boldsymbol{P}$. (2013): Effect of hCG administration during corpus luteum establishment on subsequent corpus luteum development and circulating progesterone concentrations in beef heifers. Reprod. Fertil. Devt. 26: 367-374.

- Mann, G.E.and Lamming, G.E.(1999): The influence of progesterone during early pregnancy in cattle. Reprod. Dom. Anim. 34:269-274.

- Mann, G.E. and Lamming, G.E. (2006): Relationship between the material endocrine environment, early embryo development and the inhibition of theluteolytic mechanism in the cow. Reproduction, 121: 175-180.

- Mattos, R.; Staples, C.R. and Thatcher, W.W. (2000): Effects of dietary fatty acids on reproduction in ruminants.Rev.Reprod.5:38-45.

- Mattos, R.; Guzeloglu, A.; Badinga, L.; Staples, C. R. and hatcher. W. W. (2003): Polyunsaturated fatty acids and bovine interferonmodify phorbol ester-induced secretion of prostaglandin F2 $\alpha$ and expression of prostaglandin endoperoxide synthase-2 and phospholipase-A2 in bovine endometrial cells.Bio.of Rep.69:780-787.

- Mattos, R.; Staples, C.R.; Arteche, A.; Wiltbank, M.C.; Diaz, F.J.; Jenkins TC, Thatcher, W.W. (2004): The effects of feeding fish oil on uterine secretion of PGF2alpha, milk composition, and metabolic status of periparturient Holstein cows. J Dairy Sci. 87:921-932. 
- McNeill, R.E.; Diskin, M.G.; Sreenan, J.M. and Morris, D.G. (2006): Associations between milk progesterone concentration on different days and with embryo survival during the early luteal phase in dairy cows. Theriogenology, 65, 1435-1441.

- NRC, (2001): Nutrient requirements of Dairy Cattle, $7^{\text {th }}$ edn. National Academy Press, Washington, Dc, USA.

- Parr, R.A.; Davis, I.F.; Miles, M.A. and Squires, T.J. (1993): Feedintake affects metabolic-clearance rate of progesterone in sheep. Res. Vet. Sci. 55:306-310.

- Pursley,J.R.;Kosorok,M.R.and Wiltbank,M.C. (1997): Reproductive management of lactating dairy cows using synchronization of ovulation. J. Dairy Sci. 80: 301-306.

- Sandra, F.L.; Butler, W.R. and Bruce, W. (2007): Pregnancy rate in lactating dairy cattle following supplementation of progesterone after artificial insemination. Anim. Reprod. Sci. 102: 172-179.

- SAS. (2004): Statistical analysis system. SAS User's Guide. SAS Incorporation Institute.

- Shams-Esfanabadi, N. and Shirazi, A. (2006): Effects of supplementation of repeat-breeder dairy cows with CIDR from 5-19 postinsemination on pregnancy rate. Pakistan J.Biol. Sci.9:2173-2176.

- Sklan, D.; Kaim, M.; Moallem, U. and Folman, Y. (1994): Effect of dietary calcium soaps on milk yield, body weight, reproductive hormones, and fertility in first parity and older cows. J. Dairy. Sci. 77:1652-1660. 
- Siedel, J.; Rollinger, W.; Roschlau, P. and Ziegenhorn, J. (1985): Total cholesterol, endpoint and kinetic method. In: Bergmeyer HU(ed), Methods of enzymatic analysis. Weinherim. Deer field Beach, FL, 8, PP, 139-148.

- Silvestre, F.T.; Carvalho, T.S.M. and Francisco, N. (2011): Effects of differential supplementation of fatty acids during the peripartum and breeding periods of Holstein cows: I. Uterine and metabolic responses, reproduction, and lactation. J. Dairy. Sci. 94: 189-204.

- Souza, A.H.; Silva, E.; Cunha, A.;Gümen, A.; Ayres, H.; Brusveen, D.; Guenther, J. and Wiltbank, M. (2011): Ultrasonographic evaluation of endometrial thickness near timed AI as a predictor of fertility in high producing dairy cows. Theriogenology, 75:722-733.

- Son, J.; Grant, R.J. and Larson, L.L. (1996): Effects of tallow and escape protein on lactational and reproductive performance of dairy cows. J. Dairy. Sci. 79:822-830.

- Staples, C.R.; Burke, J.M.; and Thatcher, W.W. (1998): Influence of supplemental fats on reproductive tissues and performance of lactating cows. J. Dairy. Sci. 81:856-871.

- Starbuck, G.R.; Darwash, A.O. and Lamming, G.E. (1999): The importance of progesterone during early pregnancy in the dairy cow. Cattle Practice, 7:397-399.

- Starbuck, G.R.; Darwash, A.O.; Mann, G.E.; and Lamming, G.E. (2001): The detection and treatment of post insemination progesterone insufficiency in dairy cows. In: Fertility in the High-producing Dairy Cows. BSAS, p.447, Occasional Publication No. 26.

- Stevenson, J.S. and Mee, M.O. (1991): Pregnancy of Holestein cows after post insemination treatment with a progesterone releasing intravaginal device. J. Dairy. Sci. 74: 3849-3856. 
- Thatcher, W.W.; Moreira, J.E.P.; Santos, R.C.; Mattos, R. and Lopes, $\boldsymbol{F}$. (2001): Effects of hormonal treatments on reproductive performance and embryo production. Theriogenology, 55: 75-89.

- Thatcher, W.; Drost, M.; Savio, J.; Macmillan, K.; Entwistle, K.; Schmitt, E.; Delasota, R. and Morris, G. (1993): New clinical uses of GnRH and its analogs in cattle. Anim. Reprod. Sci., 33: 27-49.

- Villarroel, A.; Martino, A.; Bondurant, H.R.; Deletang, F. and Sischo, M.W. (2004): Effect of post-insemination supplementation with PRID on pregnancy in repeat-breeder Holstein cows. Theriogenology, 61: 1513-1520.

- Washburn, S.P.; Silvia, W.J.; Brown, C.H.; McDaniel, B.T. and McAllister, A.J. (2002): Trends in reproductive performance in southeastern Holstein and Jersey DHI herds. J. Dairy Sci. 85:244-251.

- Willard, S.; Gandy, S.; Bowers, S.; Graves, K.; Elias, A. and Whisnant, $C$. (2003): The effects of GnRH administration postinsemination on serum concentrations of progesterone and pregnancy rates in dairy cattle exposed to mild summer heat stress. Theriogenology, 59:1799-1810.

- Wildman, E.E.; Wanger, P.E.; Boman, R.L.; Trout, H.F. and Lesch, T.N. (1982): A dairy cow body condition scoring system and its relationship to selected production variables in high producing Holestein dairy cattle. J. Dairy Sci., 65: 495-501.

- Wiltbank, M.; Lopez, H.; Sartori, R.; Sangsritavong, S. and Gumen, A. (2006): Changes in reproductive physiology of lactating dairy cows due to elevated steroid metabolism. Theriogenology, 65, 17-29.

- Wiltbank, M.C.; Souza, A.H.; Carvalho, P.D.; Bender, R.W. and Nascimento, A.B. (2012): Improving fertility to timed artificial insemination by manipulation of circulating progesterone concentrations in lactating dairy cattle.Reprod.Fertil.Dev.24:238-243. 
تأثثير إعطاء البروجيستيرون مقارنة بنظام تغذية يحفز إنتاجه داخلياً

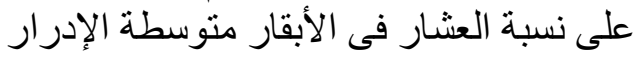

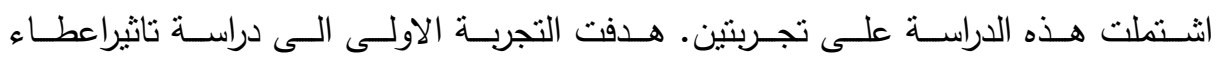

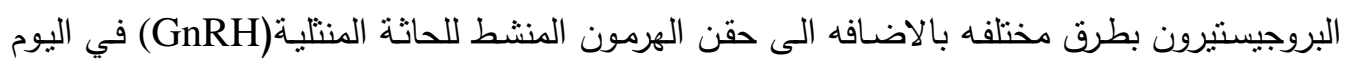

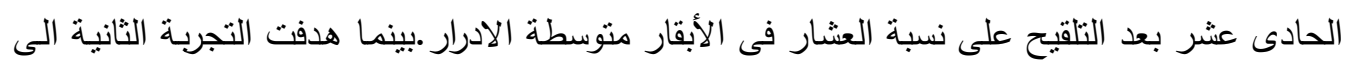

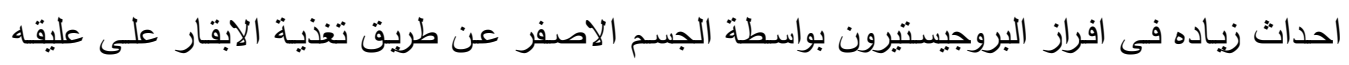

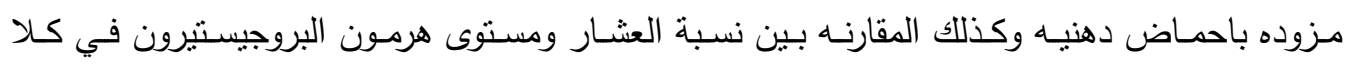
التجربتين. غذيت الأبقار (عدد= 92) في التجربـة الاولى على العليقه الضـابطه وقسمت الى الى ثنلاث

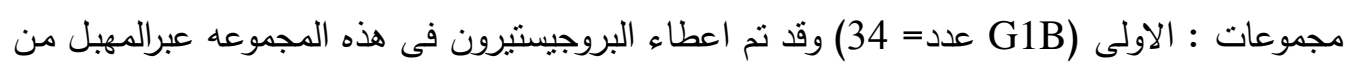

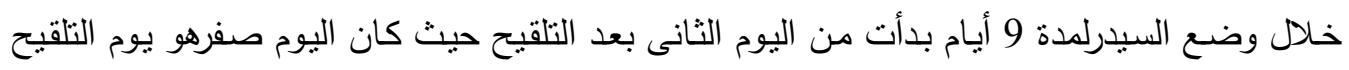

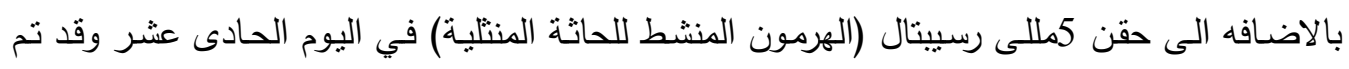

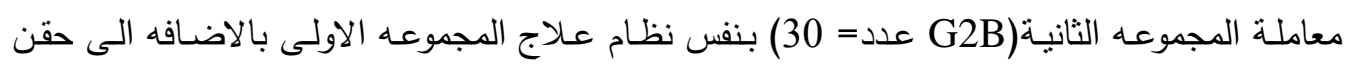

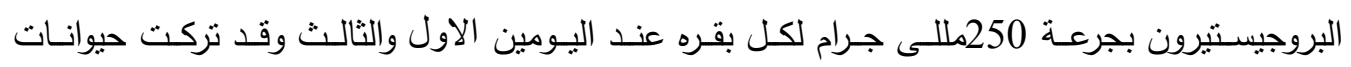
المجموعه الثالثه (G3B عدد= 32) بدون معامله كمجموعه ضابطه. غذيت الأبقار فئرون في التجربة الثانيه

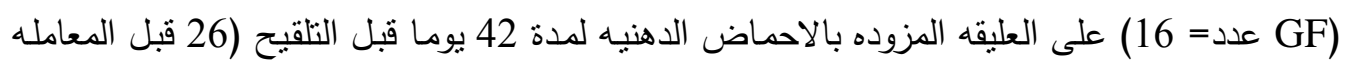

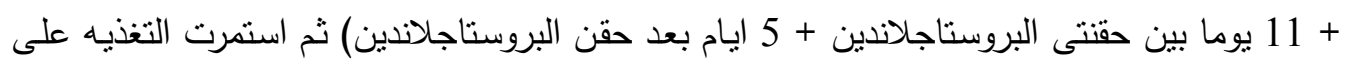
هذه العليقه حتى الولاده.

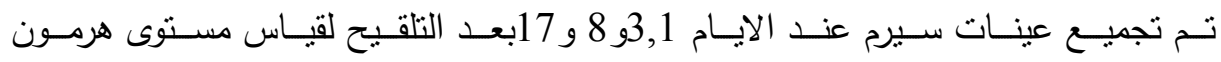

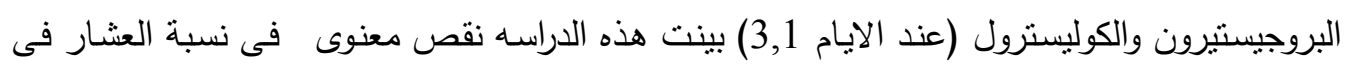

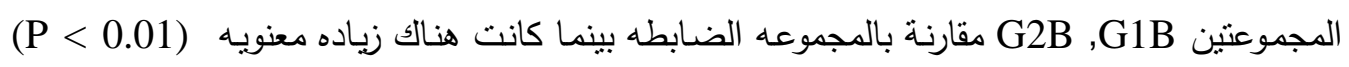

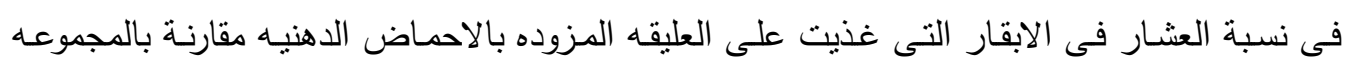

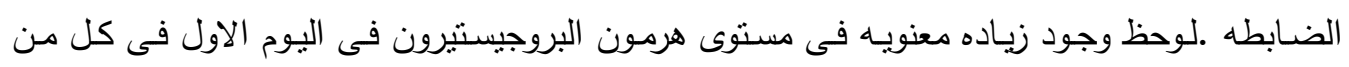

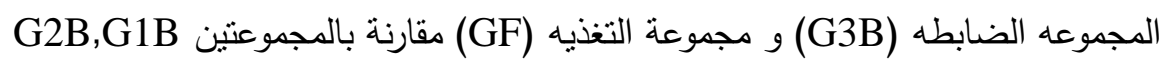
خلصت هذه الدراسه الى ان تغذية الابقار فى فترة ما حول التلقيح على عليقه مزوده باحماض

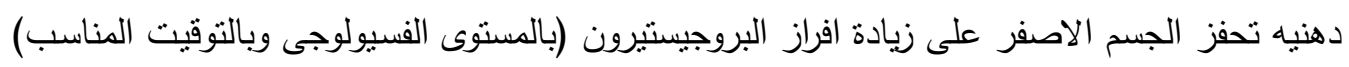
وهو بالطبع الافضل من الاعطاء الخارجى للبروجيستيرون لتحسين نسبة العشار فى الأبقار منوسطة التروجة الادرار.

$\overline{\overline{\text { Kafrelsheikh Vet. Med. J. Vol. } 14 \text { No. } 1 \text { (2016) }}}$ 